\title{
Dynamic Quantity Theory of Money: Research on Monetary Cycle and Business Cycle Based on the Concepts of Issuing Money and Operating Money
}

\author{
Liankui Gao* \\ China Original Economics Forum, Beijing 10010, China \\ *Corresponding author: Liankui Gao, Hxsszxy@163.com
}

Copyright: ( 2022 Author(s). This is an open-access article distributed under the terms of the Creative Commons Attribution License (CC BY 4.0), permitting distribution and reproduction in any medium, provided the original work is cited.

\begin{abstract}
The Quantity Theory of Money and the Theory of Credit Creation have been the major streams in the study of the quantity of money. Nowadays, monetary theory is dominated by the Quantity Theory of Money because the Monetarist School and the Rational Expectation School are both the advocates of the Quantity Theory of Money, which has resulted in a sharp decrease of scholars studying the Theory of Credit Creation. Nevertheless, the two theories will ultimately converge. Given that reason, we propose a new theory-Dynamic Quantity Theory of Money in this paper, by which the unification of the Quantity Theory of Money and the Theory of Credit Creation can be achieved. Based on the Dynamic Quantity Theory of Money, we further put forward the Theory of Money Operation Cycle, the Theory of Monetary Compensation and Theory of Investment Compensation targeting economic crises, expound why Quantitative Easing monetary policy fails and why Quantitative Easing does not cause inflation in the short term under the premise of these theories, and demonstrate the necessity of fiscal investment for rescuing economic crisis from the perspective of theories of money.
\end{abstract}

Keywords: Dynamic Quantity Theory of Money; Issuing money; Operating money, Monetary compensation and investment compensation; Monetary cycle

Online publication: January 19, 2022

\section{Monetary cycle and the failure of the static Quantity Theory of Money}

To better expound the Dynamic Quantity Theory of Money, we propose three new concepts related to money: issuing money, operating money, and money operation efficiency, in an attempt to avoid the confusion with existing concepts such as money base, narrow money, and broad money. Issuing money means the printing of money. Operating money means the creation of money by banks and other financial institutions with their credits. The quantity of operating money is dynamic at any time. The Dynamic Quantity Theory of Money is mainly aimed at operating money.

The law of quantity of money in the Dynamic Quantity Theory of Money is that there will be more money if it is used, and vice versa. The underlying mechanism is that an increase of money loans leads to the more derived savings, thereby increasing the total quantity of money in operation. The efficiency of money operation mainly depends on the speed of money turnover. The faster the money turnover, the higher the money operation efficiency.

The quantity of operating money is not determined by the central banks. Instead, it is determined by the macro economy, specifically by the credit willingness of enterprises and governments. Under which circumstances will the quantity of operating money increase? Under which circumstances will it decline? 
A cyclical law lies behind them, which means there is a cycle similar to the macroeconomic cycle that exists in operation course of money, but the money operation cycle generally has the same frequency as the macroeconomic cycle. The cyclical law of money operation is that: the operating money increases automatically during the economic boom, while its quantity declines automatically in the economic depression cycle. In summary, the quantity of operating money rises as the economy expands and falls as the economy shrinks. During the economic boom cycle, the increase of operating money is due to the drive of the strong willingness of enterprises to borrow money during the economic boom, which derives more money, resulting in the natural increase in operating money. When the economy is in recession, fewer loans are needed, quantity of derived money slumps accordingly, thus the operating currency will naturally decline. As can been seen, money operation cycle is a cycle with the same pace of macroeconomic operation. The money operation cycle is an attachment to the macroeconomic cycle. In term of the relationship between the two cycles, the money operation cycle is consequence while the macroeconomic cycle is the cause $^{[1]}$.

Besides, we should also make it clear that inflation only directly relates to the quantity of operating money, but not directly relates to the quantity of issuing money, except only in an indirect manner. The creator of operating money is not the central banks, but the investment behaviors of the governments and entrepreneurs. Therefore, we propose that "generally, it is not the central banks that create inflation, but the governments and entrepreneurs."

\section{Dynamic Quantity Theory of Money}

In the past, people only talked about the economic cycle, but not put forward the concept of monetary cycle separately. Only when we put forward the concept of monetary cycle can we easily see through the law of money movement and give better guidance for making monetary policy. The Quantity Theory of Money is a theory with long history, derived from the earlier Monetary Veil Theory, and resulted in to the Neutral Money Theory. But according to our summary of the monetary cycle above, operating money has its own cycle. In other words, its total quantity sometimes expands, sometimes shrinks. That is to say, the total quantity of operating money is dynamic, which means that insisting on the static and mechanical Quantity Theory of Money will be futile. Strictly speaking, the Quantity Theory of Money is only applicable to the era before the emergence of banks ${ }^{[2]}$. Actually, it is senseless to talk about the relationship between the issuing money and inflation after the establishment of banks and the credit creation of money. Therefore, we need to establish a Dynamic Quantity Theory of Money by absorbing the essence of the Theory of Credit Creation on the basis of the original static Quantity Theory of Money. Only in this way, can we achieve the unification of the Quantity Theory of Money and the Theory of Credit Creation. The concepts of issuing money and operating money are the bridges for the unification of the two theories.

In addition to the impact of banks, the emergence of central banks has badly hit the Quantity Theory of Money. Since the birth of central banks, the price of money has been guided by the central banks. The central banks are the decision-makers of the wholesale price of money. In the money market, there is no longer price regulation in a full sense. Actually, "the wholesale price of money determines the retail price of money" and "the retail price of money determines the supply and demand of money" are embodied in most cases, rather than "the supply and demand of money determines the price of money." Therefore, the Quantity Theory of Money has little effect when it is exposed to the central banks' money price regulation. If humans returned to the era before the emergence of banks and central banks, the Quantity Theory of Money would be definitely undisputed. The emergence of banks has driven the quantity of money from static state to dynamic state, while the emergence of central banks has shifted the money pricing right from the market to the central banks. The Quantity Theory of Money has been severely battered with little sense in reality. 
As a matter of fact, human beings have gotten rid of the shackle of the early Quantity Theory of Money since modern society. The mainstream of monetary study has been along the direction of money credit creation, such as the money theories of Mackrude, Abbott Han, and Schumpeter and Fisher's money equation. All of them are based on the Theory of Credit Creation of money. In the book Theory of Credit, Markrud clearly stated that "The essence of banks is the creation and issuance of credit, so banks are by no means the stores of lending money. They are credit-creating factories." Fisher's theory is in the same line as the Theory of Credit Creation, but the early credit creation theorists highlighted the role of credit expansion in the economic crisis before the outbreak of the economic crisis, while Fisher focused on the impact of the credit contraction on the economic crisis after the outbreak of the economic crisis. Friedman's return to the essence of the Quantity Theory of Money is retrogression in the study of monetary theory. The Rational Expectation School strengthened the theory of monetary neutrality from the perspective of rational expectations, which has caused another horrible retrogression in monetary theory. At present, the two schools are the cornerstones of the study of monetary theory and have had a huge impact on economics. Therefore, innovation for the monetary theory is urgently needed. The Dynamic Quantity Theory of Money in this paper is formed by integrating the advantages of the Quantity Theory of Money and the Theory of Credit Creation. Its core is the Theory of Credit Creation, but the analytical paradigm of the Quantity Theory of Money is incorporated through the concept of operating money. This invigorates the Quantity Theory of Money, making it full of dynamics.

\section{Why is quantitative easing not working?}

The quantitative easing monetary policy is an application of the Theory of Helicopter Money of Friedman's Monetary School. Friedman's Helicopter Money strategy is derived from his paper The Optimum Quantity of Money published in 1969. In this paper, Friedman Mann hypothesized a scenario: a helicopter dropped US dollar bills while flying over a community, and the money was picked up by the residents there. They treated the money as a windfall and used it in consumption, which would drive actual output, thus boosting the economy. This is where the Theory of Helicopter Money came. Former Federal Reserve Chairman Ben Bernanke is a faithful advocate of the Theory of Helicopter Money. He once elaborated on the operating mechanism of the theory and named it the "monetized financing fiscal plan," believing the theory is the ultimate weapon for central banks to stimulate economic growth and avoid deflation. Bernanke hyped Friedman's proposition in a speech in 2002. That is why he was called the "Helicopter Ben" by the media, because Bernanke's full name is Ben Bernanke.

Quantitative easing monetary policy was first implemented by the Japanese government. It has become a universal monetary tool worldwide after the global financial crisis in 2008. Since then, issuance of additional money has become the norm for governments to rescue economic crisis. Actually, the effect of quantitative easing monetary policy is limited while its harm is severe. The root cause is that Friedman did not distinguish between the issuing money and operating money. What increased by quantitative easing is only issuing money, rather than operating money. Only when issuing money is converted into operating money can it facilitate the economic growth. The willingness of companies and governments to invest with loans is needed in order to realize the conversion of issuing money to operating money ${ }^{[3]}$. During economic crisis, issuing money can be directly converted into operating money in China through government investment. However, in the United States, the subjects of investment are enterprises. If enterprises do not have the willingness to invest with loans, the increased issuing money cannot be converted into operating money. Therefore, the quantitative easing monetary policy will not work.

When Friedman studied the Great Depression, he observed a decrease in operating money. Unfortunately, he attributed it to the Fed's monetary tightening. Of course, the Fed's monetary policy was flawed, but the main culprit for the decrease of the quantity of money during the Great Depression is 
definitely not the Fed. Two other factors are the true cause: one is the low willingness of companies to invest with loans as we mentioned above, which results in the decline in derived money. The other is the liquidity preference stated by Keyne, a concept that is elusive for ordinary people. We can put it in other words: "Cash is king," the troublemaker is the irrational emotions of human beings. During the economic crisis, these two factors work together, resulting in a slump in the quantity of operating money. Therefore, by means of increasing issuing money, the effect is bound to be limited. Furthermore, quantitative easing means that money price is extremely low, which makes it difficult to be compatible with financial institutions in incentive mechanisms, inhibiting the willingness of financial institutions in lending business. This also blocks the transfer of money to real economy.

\section{Double compensations: Money compensation and investment compensation during economic crisis}

According to our view stated above that the monetary cycle is consistent with the business cycle, when an economic crisis breaks out, both money and investment actually shrinks. To get rid of the economic crisis, compensations are needed for both money and investment. The governance of economic crisis is a process of "double compensations." From the perspective of the Dynamic Quantity Theory of Money, investment compensation is fundamental, because investment compensation will naturally bring about monetary compensation, and loans for investment will also derive savings, leading to an increase in operating money. However, if only the measure of monetary compensation is taken in a country, it is still difficult to form investment compensation. Even if it is formed, it will function with a delay.

Monetary compensation only works for a small quantity of countercyclical industries that require investment during the depression, but there are few countercyclical industries actually. It is too difficult to propel the vast majority of the pro-cyclical industries by relying on the ripple effect triggered by so few countercyclical industries. From the perspective of the Dynamic Quantity Theory of Money, investment compensation is the major means for the governance of economic crises, and the investment loan behavior in the investment compensation process will objectively result in monetary compensation. Therefore, according to the traditional static Quantity Theory of Money, quantitative easing is effective in increasing money to rescue the economic crisis, but from the perspective of the Dynamic Quantity Theory of Money, it is obvious that monetary policy cannot fix the economic crisis fundamentally. To quickly provide rescue to the economic crisis, the introduction of policy for investment increase is necessary. Of course, government investment must be the dominant part of the increased investment during the economic crisis. In this way, government investment policies will nurture double compensations in both fiscal and monetary dimensions.

As a witness of the Great Depression, Keynes did not write much content concerning money. Only the concepts of liquidity preference and liquidity trap are put forward by Keynes' in his monetary study in the General Theory. His focus of study is finance. In terms of studies, Keynes' theory is pragmatic, while Friedman's Empirical Monetary Theory is impractical, and his theoretical propositions are also superficial and unscientific, because rescuing an economic crisis is a process of double compensations - investment compensation and monetary compensation, with investment compensation being the mainstay, and monetary compensation being a supplement. The monetary compensation is only applicable for stimulating the countercyclical industries.

\section{Why does quantitative easing not trigger inflation?}

According to the Dynamic Quantity Theory of Money, when the economy is in depression, the quantity of operating money automatically declines. Quantitative easing results in the increase of issuing money, but there is little effect on total quantity of operating money. Since the total quantity of operating money almost 
remains unchanged or even less. There surely will be no inflation. Inflation is related not only to the monetary base, but also to the quantity of operating money. In this paper, the additional issuance of money during economic depression is referred to as monetary compensation. Monetary compensation means the monetary regulation behavior by compensating the decreased operating money through the issuance of additional money during economic crises. It aims to maintain the stability of total quantity of operating money. Monetary compensation is not the excessive insurance of money. It does not increase the total quantity of operating money, but only helps maintain the stability of the total quantity of operating money, nor does it cause inflation during economic depression. When the economic depression fades away and economic prosperity comes, the central banks may withdraw the quantitative easing policy and shrink the issuance of additional money. In general, the total quantity of operating money can be maintained unchanged, thus there will be no inflation and deflation ${ }^{[4]}$. In short, the Dynamic Currency Quantity Theory proposes that inflation and deflation are only related to the quantity of operating money, and irrelative to the quantity of issuing money. In fact, the United States did not undergo any significant inflation in several rounds of quantitative easing, which is a proof. Nevertheless, concerns of human beings about the possibility of inflation caused by quantitative easing have been lingering. Quantitative easing did cause inflation if we consider it from the perspective of the traditional static Quantity Theory of Money. But when we apply the Dynamic Quantity Theory of Money, "quantitative easing not cause inflation" can be easily explained.

\section{Central banks' responsibility from the perspective of Theory of Monetary Compensation}

An additional responsibility is added to the central banks according to the Dynamic Quantity Theory of Money, that is, the central banks have the obligation to maintain the stability of the total quantity of operating money in the entire society. The public should also abandon the ideological constraints from traditional static Quantity Theory of Money, and think about money matters from the perspective of the Dynamic Quantity Theory of Money. If we move our focus of attention from issuing money to operating money, the concern over "Quantitative easing does not cause inflation" will disappear naturally. The proposition from Friedman's single rule of maintaining stable growth of issuing money is wrong. The central banks' responsibility is to maintain the stability of total quantity of operating money. Increasing the quantity of issuing money cannot effectively increase the quantity of operating money. Instead, increasing investment is the right approach to increase the quantity of operating money.

Of course, the Theory of Monetary Compensation proposed in this paper is mainly for eliminating inflation expectations after the implementation of quantitative easing. Since the predecessors did not witness quantitative easing, they would not think so profoundly. The Theory of Monetary Compensation can help get rid of the ideological constraints of the static Quantity Theory of Money. Friedman insisted on the Quantity Theory of Money, which made him unable to learn from the Theory of Credit Creation. In this paper, the Quantity Theory of Money and the Theory of Credit Creation are integrated and give birth to the Dynamic Quantity Theory of Money, and the concepts of monetary cycle and Monetary compensation are put forward. They contribute to the formation of the set of scientific theory of monetary cycle operation.

\section{Viewpoint on savings from the perspective of the Dynamic Quantity Theory of Money}

Savings are emphasized in Keynesian Economics. In reality, economists often use the level of savings rate to explain the economic development of some countries. The savings rate and investment rate are also highlighted in foundation of the Harold-Doma model in Economic Growth Theory. But from the perspective of Theory of Credit Creation and the Dynamic Quantity Theory of Money, money can grow automatically. It is unnecessary to attach more emphases to the savings rate because many savings are 
derived from loans. When we encourage borrowing, savings are automatically created. Similarly, government investment does not have a crowding-out effect on private investment, because the law of money operation is that the more money is used, the more it will be produced. The loans used for government investment can also create savings for private financing. Therefore, government investment does not have a crowding-out effect on private investment. On the contrary, it has a promotion effect because government loans can create credit funds for private enterprise loans.

Although there is the concept that savings are equivalent to investment in Keynesian economics, expanding resident savings are not necessary for investment expansion. Social investment can be implemented even if resident savings are in negative value. Corporate savings account for most part of the total savings in macroeconomic operation. At present, there will be enough savings by reducing saving reserve, if necessary. Encouraging residents to save money in banks only has a social significance but not economically.

The quantity of savings is related to the efficiency of money operation. The higher the money operation efficiency, the more savings, and vise versa. Therefore, to promote economic growth, we should increase investment and improve money operation efficiency, but not to increase savings. As investment increases and money operation efficiency is elevated, and savings will naturally increase. This is the real operation law of savings and investment. In the Harold-Doma model, an effect has mistakenly been considered a cause.

\section{Innovative points of the Dynamic Quantity Theory of Money}

The concepts of issuing money, operating money and money operation efficiency are proposed in this paper, which makes it possible to explain many problems in monetary theory. There are "M0," "M1," "M2," and "M3" in monetary theory. But these are statistical concepts based on monetary stratification, not theoretical concepts. If we want to improve monetary theory theoretically, new theoretical concepts must be created. In fact, from the early Theory of Credit Creation to Fisher equation, Debt-Deflation Theory, and PostKeynesian Endogenous Monetary Theory chronologically, the development path of the theory of money operation is very clear. The Monetary Veil Theory and the Quantity Theory of Money are both the simple understanding of money in the very early days of mankind. They should have been abandoned long time ago. Why the retro and resurgence of the Quantity Theory of Money appeared sometime in the history. This is actually a problem of theoretical unification. What I am doing is the unification work. If no one carries out the theoretical unification work, there will always be a resurgence of the Quantity Theory of Money.

In addition, the concept of money operation cycle is proposed in this paper for expounding the relationship between monetary cycle and business cycle, which is not available in other theories, and the double compensations - the Theory of Monetary Compensation and Theory of Investment Compensation and relevant concepts are proposed for economic crisis governance. This has not only innovated the theory of money but also dialectically unified Friedman's and Keynesian theories on economic crisis, which is not found in other schools of theories. The Dynamic Quantity Theory of Money and related concepts are not only a conceptual innovation, but also a revolution of thinking.

\section{Conclusion}

In summary, after we upgrade the Quantity Theory of Money from "static" to "dynamic," many touchy economic issues related to inflation and government investment can be easily addressed. Observation of the economy should not only be focused on the total quantity of issuing money. We should pay more attention to the total quantity of operating money. The responsibility of the central banks is to maintain the stability of the total quantity of operating money in the entire society, rather than the stability of the money 
base. The quantitative easing during the economic crisis is only a compensation for the cyclical contraction of the operating money, but the central banks' monetary compensation by increasing the money base is only a "temporary cure." The fiscal compensation through fiscal policy can also indirectly form monetary compensation, so the goal of double compensations - investment compensation and money compensation - during the economic crisis can be attained, thus curing the root cause of the economic crisis. The main force for creating the operating money has never been the central banks, it is the behaviors of investment with loans by governments and enterprises.

\section{Disclosure statement}

The author declares no conflict of interest.

\section{References}

[1] Kang K, 2019, The Modern Significance of David Hume's Theory of Monetary Quantity Modern Commercial Bank. Modern Commercial Banking, 2019(11): 21-23.

[2] Lu Y, 2019, Analysis on the Development of Modern Money Demand Theory Modern Economic Information. Modern Economic Information, 2019(015): 340.

[3] Liu Y, 2017, Social Financing Scale and Monetary Quantity Theory Shanghai Economic Research. Shanghai Journal of Economics, 2017(10): 22-35.

[4] Zhao W, Liu S, 2017, Reshaping Monetary Theory: A Framework of Decomposition and Unification Analysis Financial Research. Journal of Finance and Economics, 2017(09): 4-20.

Publisher's note

Bio-Byword Scientific Publishing remains neutral with regard to jurisdictional claims in published maps and institutional affiliations. 